\title{
ECO-LABELLING OF ACCOMMODATION FACILITIES AND ITS PERCEPTION BY RURAL TOURISTS: CASE STUDY OF VOJVODINA
}

\author{
Milan Bradić1, Ljiljana Kosar², Lukrecija Djeri ${ }^{3}$, Svetlana Vukosav ${ }^{4}$, Vuk Garača $^{5}$
}

\begin{abstract}
Summary
With transportation, hotel industry eco-efficiency forms the basis of the eco-efficiency in tourism operations. Although the tourism industry is a huge consumer, very few studies has been published on energy saving and renewables in terms of stakeholders' attitudes on the topic. One of the ultimate goals of sustainable development is to foster responsible environmental behaviour not only for tourism operators, but also for tourists themselves. This paper represents the results of qualitative and quantitative research that was conducted in 59 accommodation facilities in rural areas of Vojvodina. The main task of the research was to explore possibilities of improving the environmental aspects of environmental responsible consumer behaviour in the hospitality industry. The aim of the research is to improve the tourism and hospitality market participants understanding of the relationship between positive consumer environmental protection attitude and responsibility with business standards in hospitality industry in rural areas. The research findings show the nature of such relationships.
\end{abstract}

Key words: sustainable tourism, hotel management, ecolabeling, Green consumers, Environmental management, Rural tourism

JEL: Q5, O13, O14, Z320

1 Milan Bradić Ph.D., Assistant Professor, University of Novi Sad, Department of Geography, Tourism and Hotel Management, Dositeja Obradovića Square no. 3, Novi Sad, Serbia, Phone: +381 214852 848, E-mail: milanbradic@gmail.com

2 Ljiljana Kosar Ph.D., Full Professor, The College of Hotel Management, Kneza Viseslava Street no. 70, Belgrade, Serbia, Phone: +381 112543 972, E-mail: 1jiljakosar@hotmail.com

3 Lukrecija Djeri Ph.D, Associate Professor, University of Novi Sad, Department of Geography, Tourism and Hotel Management, Dositeja Obradovića Square no. 3, Novi Sad, Serbia, Phone: +381 21450 105, E-mail: djerilukrecija@gmail.com - corresponding author

4 Svetlana Vukosav, Ph.D, Assistant Professor, University of Novi Sad, Department of Geography, Tourism and Hotel Management, Dositeja Obradovića Square no. 3, Novi Sad, Serbia, Phone: +381 214502 848, E-mail: cecamobr@yahoo.com

5 Vuk Garača Ph.D, Assistant Professor, University of Novi Sad, Department of Geography, Tourism and Hotel Management, Dositeja Obradovića Square no. 3, Novi Sad, Serbia, Phone: +38121 4502 836, E-mail: vuk garaca@yahoo.com

EP 2017 (64) 1 (205-219) 


\section{Introduction}

Over the last few decades (especially with climate change), concerns related to the environment have progressively escalated (Laroche, Bergeron, Barbaro-Forleo, 2001; Keller, 2010). Many lodging customers, being aware of the environmental damages and the wasting/harming of environmental resources caused by hospitality activities, now look for facilities that follow eco-friendly practices (APAT, 2002; Han, Hsu, Sheu, 2010).

Sustainable consumption is product and resources consumption at rates that stand in concordance with sustainable development. It is observable that current rates of consumption are unsustainable, environmentally unfriendly and lead to resources depletion. Consumers play a fundamental role in enhancing sustainable development through purchase decision. (ISO 14020, Environmental labels and declarations General principles).

With the growing number of customers seeking "green", being a green accommodation can provide a basis for good marketing strategies on which its environmentally friendly practices may help position it differently in the competitive arena. Thus, the green accommodation business is believed to be a growing niche of lodging industry (Manaktola, Jauhari, 2007). One of the ultimate goals in sustainable development, especially in rural areas is to foster responsible environmental behaviour not only for tourism operators, but also for tourists themselves (Gossling, 2002).

Recently, international tourism policy is aiming at the improvement of the existing infrastructure, the lengthening of the operation season, the improvement of alternative forms of tourism (i.e. eco-tourism, health tourism etc.) but, always minding environment. Nowadays, many countries strongly encourage positive environmental performance of services and products.

First steps in the introduction of green technologies in accommodation were made in the eighties of the last century. Initial success was achieved in North America, but for decades the activities of "greening" the hospitality operations spread to other continents. Professional organizations from global to the local level, as well as government and non-government organizations in many countries became involved in this process. Soon, the management structure of the industry realized the need of introducing a system of operations and programs relating to the protection of the environment through environmental management, hospitality environmental programs, and assessment of environmental impacts, monitoring indicators and environmental control (Holcomb, Upchurch, Okumus, 2007; Bhattacharya, Sankar, Korschun, 2008). Managers, consumers and other participants in tourism notice the positive results of implementation of environmental responsibility, as part of corporate social responsibility (Waldmann, 2005; Nicolau, 2008). Using the recommendations based on the results of this research the intention of the authors is to encourage formal and informal institutions and organizations to introduce environmental standards in the hospitality industry. 


\section{Methodology}

The main research concerns the collection of possible useful information and suggestions from guests in accommodation facilities in rural areas of Vojvodina, in order to explore possibilities of improving environmental protection. Although there are various criteria for defining rural areas (Gajić, 2015), due to the simplification of research, each settlement under 10,000 inhabitants was considered for rural.

The main hypotheses of the research are:

- $\quad$ Hypothesis 1 - There is no Environmental Management System in accommodation facilities in rural areas in Vojvodina.

- $\quad$ Hypothesis 2 - Regardless to their socio-demographic characteristics, guests are interested in the implementation of environmental programs in accommodation facilities which they stay.

- $\quad$ Hypothesis 3 - The best way to introduce the program of enviromental operations in Vojvodina and Serbia's accommodation industry is certification through the official legal classification and star rating system of hospitality facilities.

The questionnaire used to collect data in the study consists of series of questions concerning guests thoughts on environmental issues, eco-labels, willingness to participate such programs and competence of government in this area. The answers were in the form of grades (Likert scale, 1 to 5 range, 1 - strongly disagree to 5 - strongly agree), which allowed easier statistical analysis.

\section{Environmental aspects of management in accommodation industry}

World accommodation industry has (not only) achieved physical growth in tourist, but also spread to environmentally attractive locations in preserved nature. International hotel companies, introducing environmental standards, affect the change of the relation towards the territory by establishing and strengthening awareness of its friability, the need to protect and preserve its original features. This process is particularly important for rural areas, where the consequences of irresponsible behaviour can be devastating (Randelli, Romei, Tortora, 2014).

Eco-accommodation is a type of accommodation in ecotourism, where the philosophy and principles of ecotourism meet. This concept includes educational and experiential perspective, combined with the philosophy of environmental protection. This means that in addition to basic hospitality services and quality tourist experience, which includes experience of tourists and learning about safety, eco-accommodation must provide adequate care for the environment. Eco-accommodation, by its nature, must meet basic ethical principles, as especially observed in small impact on their environment. Planning potential impact can be observed through minimizing influence of roads that lead to eco-accommodation, further, through its architecture, which must be in the style of the local cultural heritage and without compromising aesthetic value, as well as through the management and operations. When 
possible, eco-accommodation uses renewable energy sources as solar or wind energy, obligatory working on waste water treatment and recycling of waste (Stojanović, 2006).

Numerous studies show that sustainability programs that are implemented in the tourism industry have no meaning, or at least do not have a full meaning if consumers (i.e. guests) are not included. Here, a special role is played by the processes which serve as a means of promoting sustainability and refer to the involvement of guests in activities where they can directly and empirically experience ecological operations. In most (not all) cases guests would not mind when service is affected by sustainable efforts (Kasim, 2007; Chan, Lam, 2003; Berezan, Raaba, Yoob, Lovea, 2013).

Some papers have shown that the best way to track guests service satisfaction results is insistence on feedback through questionnaires and/or comments. Guests are those who give the final assessment of the efforts made by the management to raise level of sustainability and responsibility. Word-of-mouth practice should be represented in hospitality organizations of all sizes, from individual small rural properties to global hotel groups and chains (Juwaheer, 2004; Manaktola, Jauhari, 2007).

Surely one of the ways to achieve progress in the field of ecological management should be the acceptance and certification of a quality system that deals with this issue. Positive examples can be found in the surrounding of Vojvodina (Serbia), in Romania, Slovenia and Hungary (Tomescu, 2011).

\section{Application of clean technologies in the international accommodation industry}

The idea of application of green technologies in accommodation industry is not new, but only recently the necessity of their wider application has been recognized. Just one large hotel can have an impact on the environment which is equal to the impact of all eco-resorts in the whole region together. Problems with eco accommodation are of economic and logistic nature (Sweeting \& Sweeting, 2003).

The basic and ideal principle for the realization of the environmentally friendly project or facility, is that the facility has so-called zero footprint, i.e. zero impact on the environment. One should know that a zero footprint is virtually impossible to achieve, but people can try to achieve this value as close as possible.

Energy efficient construction and environmentally friendly materials is the beginning of ecologically oriented business philosophy (Hook, 2009). Programs of using various forms of "clean" energy are increasingly being applied in the hotel industry, as well as harmless or less harmful materials to maintain hygiene (UNWTO, 2011). Sustainable energy is an energy efficient method of production and use which has less harmful environmental impact. Sustainable building is certainly one of the important segments of sustainable development, and it includes the use of building materials that are not harmful to the environment, energy efficiency of buildings and management of the waste from construction and demolition of buildings (IHP, 2005). Energy and ecologically sustainable architecture seeks to: 


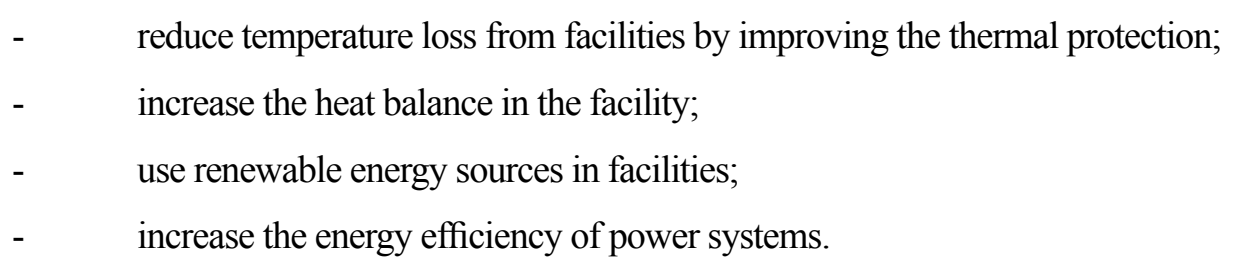

However, as the main external factor of the temperature change is the Sun, special attention in modern architecture is paid to the protection from the Sun and so-called - passive architecture. Architecture highlights the acceptance of sunlight and protection from excessive sunlight, because even the passive heat gains must be controlled and optimized in a satisfactory whole. Modern passive facilities are nowadays defined as structures without active heating systems with conventional energy sources.

Modern so-called daylight systems use optical devices to create a reflection, breaking of light beams or for active and passive reception of light. Therefore, these systems should be included in the architecture even in the earliest stages of design.

Renewable energy sources in facilities may be different - the kinetic energy of water, wind, solar energy, and bio fuels, biomass, landfill gas, geothermal energy, etc...

Water and waste management is also of great importance. Hospitality properties of various sizes, with differing technical, financial, knowledge and managerial capacities could address the challenge of implementing water and waste management and obtain commercial benefit (Kasim, Garsoy, Okumus, Wong, 2014).

Principle $\boldsymbol{R} \boldsymbol{R} \boldsymbol{R}$ is base for any business which should be in compliance with the clean environment (RRR or Reduce, Reuse and Recycle). There is often additional $4^{\text {th }} \mathrm{R}$ which indicates Report or performs (NCDPEA, 2010).

Eco-labels in tourism and hospitality industry: Eco-labels within tourism sector result from the control of ecological coherence with certain regulations and confirm that tourism company, facilities, product, process, service or management system complies with prescribed ecological standards and criteria. Ecological label is not equal to the reward for environment protection, which recognises "leading examples of natural and cultural heritage of our planet in tourism industry" (UNWTO). The rewards for nature protection are periodical as a rule (annual rewards), whereas eco-labels are valid throughout the period of certain criteria are applied.

Tourism services decide upon introducing environment protection measures in their businesses due to several factors. First, to avoid pollution effects by mass tourism. Second, it is important to become recognised at the market, which also results in economic effects. Obtaining the eco-label has the following positive effects: improving reputation, strengthening market position, improved risk management, profit management, and human resource management, lower operational expenditures, etc.

The sum of all positive factors that emerge from ecologically oriented activity is reflected in economic efficiency of the enterprise, but only for medium or long periods (Bradić, 2011). 
It is worth mentioning Green Label, Green Globe 21, Energy Star, Viabono, Ecotel and EU Eco-label as the most frequent and globally recognizable eco-labes in tourism and hospitality.

\section{Determination of the sample and data collection}

In determining the quantitative research coverage, all officially classified accommodation facilities (hotels, motels, pensions, tourist villages, serviced apartments, hostels, rural touristic households etc.) in rural areas in Vojvodina were asked to participate in it (to allow guests questioning).

Preparatory steps for data collecting were carried out in the period from $15^{\text {th }}$ January to $31^{\text {st }}$ February, 2015. The main collection and updating of data was carried out from $10^{\text {th }}$ March to $1^{\text {st }}$ August, 2015.

Positive reply to our research appeal was obtained from guests in 59 facilities (located all around Vojvodina).

Table 1. Average hotel capacity (number of beds) by categories

\begin{tabular}{|l|c|c|c|c|}
\hline & $\begin{array}{c}\text { Number of } \\
\text { accommodation } \\
\text { facilities }\end{array}$ & Number of beds & $\begin{array}{c}\text { Average number of } \\
\text { beds }\end{array}$ & $\begin{array}{c}\text { Average number of } \\
\text { employees }\end{array}$ \\
\hline TOTAL & 59 & 1,097 & 18.69 & 10.74 \\
\hline
\end{tabular}

Source: The author's calculations based on Survey data, 2015.

The questionnaires were distributed to guests in each facility. Simple random sampling was applied to obtain total 718 valid questionnaires (in all 59 accommodation facilities).

\section{Environmental aspects of accommodation industry in Vojvodina}

Presence/absence of international environmental business standards was one of the tests in the study. Extremely negative indicator is the fact that at the time of the research as much as 55 accommodation facilities (94\%) did not possess any certificate of international business standards. Another major negative surprise is the fact that only one facility has some of the international standards for environment (ISO 14001). That means Hypothesis 1 is mostly proven.

Apart of the research is concerned with issues regarding guests' opinions on the environmental aspects of responsible management and eco-labelling in hotel industry. With regard to the fact that Serbia started accession negotiation for joining the EU, certain issues refer to the EU eco-label for tourist accommodation services.

First, descriptive statistical data analysis was conducted within statistical analysis. The obtained results were used to describe the attitudes of hotel guests to the need of introducing environmental standards and eco-labels in the accommodation industry in rural areas of Vojvodina.

Table 2 shows average scores on questions relating to the average attitudes of guests, middle absolute deviation and standard deviation. 
Table 2. Descriptive statistical analysis of the responses of rural tourists in Vojvodina

\begin{tabular}{|c|c|c|c|c|c|c|c|c|}
\hline Attitude* & Min & Max & \begin{tabular}{|l|}
$\mathbf{I}$ \\
\end{tabular} & $\mu$ & $\mathbf{M}_{0}$ & $\mathbf{M}_{e}$ & $\mathbf{D}$ & $\sigma$ \\
\hline $\begin{array}{l}\text { In accommodation you are } \\
\text { staying, great attention is paid to } \\
\text { environmental issues. }\end{array}$ & $1 * *$ & 5 & 4 & 3.55 & 4 & 4.00 & 0.107 & 1.118 \\
\hline $\begin{array}{l}\text { I am familiar with some of the eco- } \\
\text { labels for tourist facilities. }\end{array}$ & 1 & 5 & 4 & 3.26 & 4 & 3.00 & 0.131 & 1.370 \\
\hline $\begin{array}{l}\text { I am familiar with eco-label EU - } \\
\text { daisy flower. }\end{array}$ & 1 & 5 & 4 & 3.05 & 1 & 3.00 & 0.149 & 1.560 \\
\hline $\begin{array}{l}\text { Hotels that have received the eco- } \\
\text { label are better positioned in the } \\
\text { market. }\end{array}$ & 1 & 5 & 4 & 3.84 & 4 & 4.00 & 0.092 & 0.964 \\
\hline $\begin{array}{l}\text { Serbia should introduce one of the } \\
\text { internationally recognized eco-labels } \\
\text { for accommodation industry. }\end{array}$ & 2 & 5 & 3 & 4.53 & 5 & 5.00 & 0.062 & 0.646 \\
\hline $\begin{array}{l}\text { Serbia should introduce the eco-label } \\
\text { of the European Union. }\end{array}$ & 1 & 5 & 4 & 4.26 & 5 & 5.00 & 0.092 & 0.956 \\
\hline $\begin{array}{l}\text { Serbia should introduce its own eco- } \\
\text { label for accommodation industry. }\end{array}$ & 1 & 5 & 4 & 3.70 & 5 & 4.00 & 0.133 & 1.384 \\
\hline $\begin{array}{l}\text { Eco-labels could be one of the } \\
\text { specializations within the star rating } \\
\text { system. }\end{array}$ & 1 & 5 & 4 & 3.91 & 5 & 4.00 & 0.101 & 1.059 \\
\hline $\begin{array}{l}\text { Eco-labels can contribute to greater } \\
\text { respect and recognition of tourism in } \\
\text { Serbia. }\end{array}$ & 2 & 5 & 3 & 4.38 & 5 & 5.00 & 0.075 & 0.779 \\
\hline $\begin{array}{l}\text { The introduction of the eco-label } \\
\text { for accommodation industry would } \\
\text { represent a major expense for hotel } \\
\text { companies. }\end{array}$ & 1 & 5 & 4 & 3.47 & 3 & 3.00 & 0.106 & 1.102 \\
\hline $\begin{array}{l}\text { With the introduction of eco-labels, } \\
\text { accommodation facilities could } \\
\text { increase the cost of services and } \\
\text { products. }\end{array}$ & 1 & 5 & 4 & 3.10 & 4 & 3.00 & 0.128 & 1.333 \\
\hline $\begin{array}{l}\text { The result of the introduction of eco- } \\
\text { labels would be the increase of the } \\
\text { quality of accommodation offers. }\end{array}$ & 1 & 5 & 4 & 4.02 & 5 & 4.00 & 0.105 & 1.097 \\
\hline $\begin{array}{l}\text { Accommodation facilities should } \\
\text { aspire to join the system of eco- } \\
\text { labelling if introduced in Serbia. }\end{array}$ & 2 & 5 & 3 & 4.25 & 5 & 4.00 & 0.083 & 0.862 \\
\hline \multicolumn{9}{|c|}{$\begin{array}{l}* \text { Values of the attitudes were evaluated in the range } 1-5 \text { where } 1 \text { is -not agree at all, } 2 \text { - mostly disagree, } \\
3 \text { - neither agree nor disagree, } 4 \text { - mostly agree, } 5 \text { - strongly agree. } \\
* * \text { where Min is - minimum value of a given response, Max - maximum value of the given response, } \mathrm{I}-\text { variation } \\
\text { interval, } \mu \text { - arithmetic mean of given responses, } \mathrm{D} \text { - mean absolute deviation, } \mathrm{M}_{\mathrm{e}}-\text { median, Mo - the mode and } \\
\sigma \text { - standard deviation }\end{array}$} \\
\hline
\end{tabular}

Source: The author's calculations based on Survey data, 2015.

Correlation analysis urges to answer the question whether there is statistical relationship between socio-demographic characteristics of the respondents (gender - GEN, age group - AGE, Monthly income in EUR - INC, education level - EDU), characteristics of the accommodation they stayed in (star rating - STARS, facility type - TYPE, service potential - SERV) and the score given by the guests for ecologically oriented business of facilities - 
SCORE. Accommodation facility rating is done according to official classification which is represented by the number of stars. Facility type is based according to the motive of guest stays. For the purposes of this research a simplified version is based in two basic (conditioned) groups - business and holiday properties. Relative relationship between business and holiday hotels in the observed sample was 91\%:9\%. Service potential of facilities (SERV) is the ratio between total number of beds and total number of employees.

The fact that only one hotel implemented some of international environmental standards (ISO 14001) prevented further statistical analysis on whether presence/absence of these standards has impact on guests' perception of ecological effect.

After the analysis completion the obtained results were presented in total in Table 3.

Table 3. Correlation Analysis

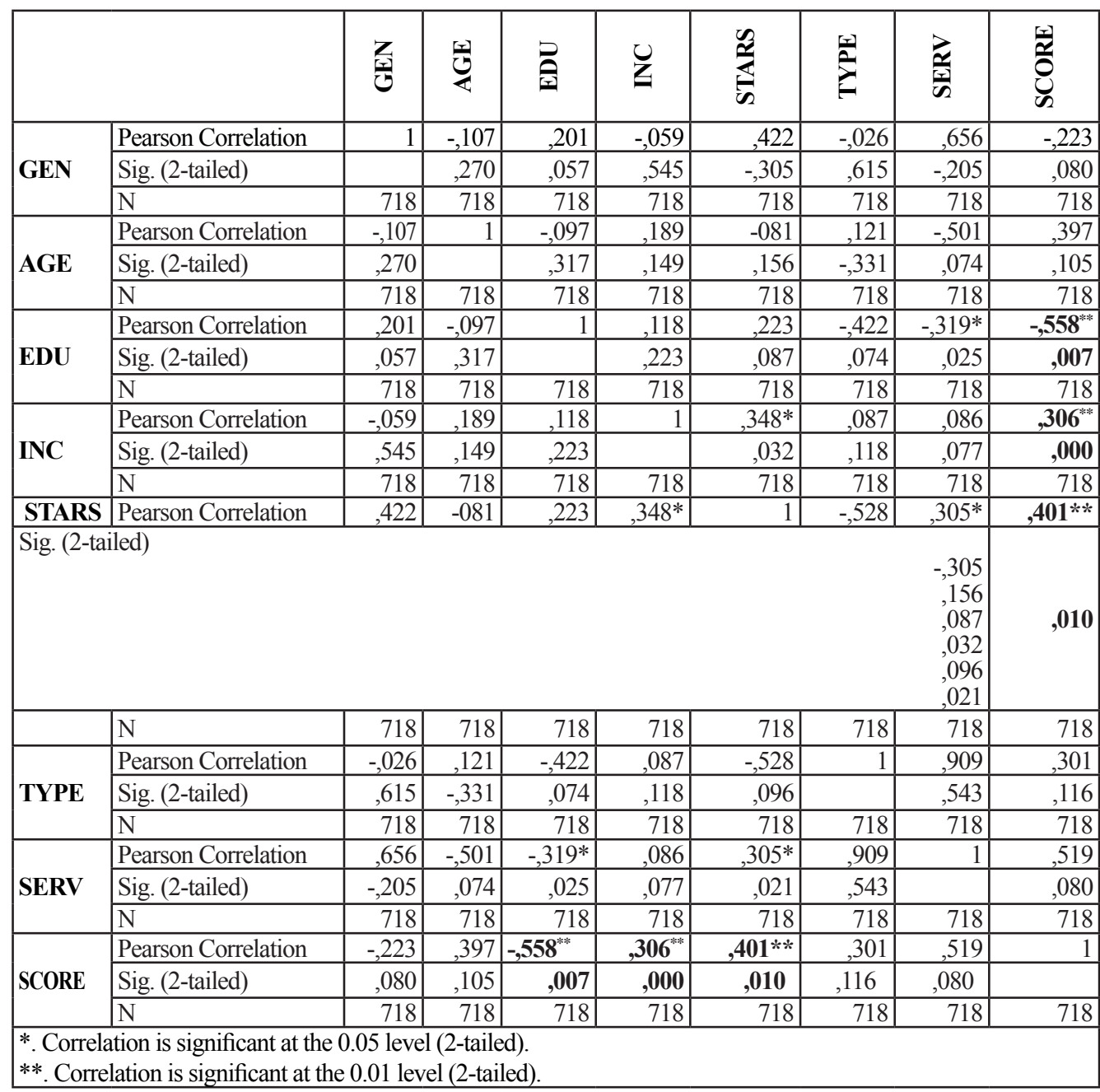

Source: The author's calculations based on Survey data, 2015. 
It is noticeable that the respondents with higher education level gave more strict scores to ecological standards of accommodation facilities. The reason for this may be higher ecological awareness compared to guests with lower education level.

However, the scoring of ecological effect by the guests is influenced by various factors. Since correlation showed that there is positive relationship between the number of stars and eco-scores of guests, this leads to a conclusion that one of the ways to introduce ecolabelling in hospitality is to use additional label to the present star rating system. In order to give more detailed explanation about the impact hotel category (STARS) might have on guests' scoring (SCORE) of ecological effects of accommodation facilities, we applied regression analysis method.

Subsequent to the verification of variables conditions for linear regression analysis, various models were tested and the appropriate one was formed. Dependent variable is the score given by the guests (SCORE), whereas control variables are the number of stars (STARS), service potential (SERV) and joint impact of socio-demographic characteristics of the respondents (DEM).

$\mathrm{SCORE}=\alpha_{0}+\alpha_{1} \mathrm{STARS}+\alpha_{2} \mathrm{SERV}+\alpha_{3} \mathrm{DEM}$

Table 4 shows the statistical indicators of the presented model.

Table 4. Model Summary

\begin{tabular}{|c|c|c|c|c|r|r|}
\hline Model & R & $\mathbf{R}^{\mathbf{2}}$ & $\mathbf{F}$ & df1 & df2 & Sig. F Change \\
\hline 1 & $.609^{\mathrm{a}}$ & .502 & 3.429 & 6 & 60 & .006 \\
\hline
\end{tabular}

Source: The author's calculations based on Survey data, 2015

The obtained results show the significance sig. $=0.006$, which implies that the error risk is under $1 \%$. Thus, we may claim that dependent variable (the score given by the respondents on ecological effect of accommodation facilities) is in statistically dependent correlation with the observed predictors - facility category, service potential, and joint impact of socio-demographic characteristics of the respondents. Since the coefficient of determination is $\mathrm{R}^{2}=0.502$, total $50.2 \%$ correlation between variables is explained by this model, whereas the rest is under some other impacts. The value of linear correlation coefficient with the observed variable (SCORE) and predictors (STARS, SERV, $\mathrm{DEM}$ ) is $\mathrm{R}=0.709$ indicating that dependent variable and independent variables in relative strong correlation.

Table 5 shows the values of standard regression coefficients for each variable and their significant values. 
Table 5. Regression Coefficients of Model

\begin{tabular}{|l|l|r|r|r|r|r|}
\hline & & \multicolumn{2}{|c|}{$\begin{array}{c}\text { Non-standardized } \\
\text { Coefficient }\end{array}$} & $\begin{array}{l}\text { Standardized } \\
\text { Coefficient }\end{array}$ & & \\
\hline Model & & \multicolumn{1}{|c|}{$\mathrm{B}$} & \multicolumn{1}{|c|}{ Std. Error } & \multicolumn{1}{c|}{ Beta } & \multicolumn{1}{c|}{$\mathrm{t}$} & \multicolumn{1}{c|}{ Sig. } \\
\hline a. & (Constant) & 1.262 & .641 & & 1.972 & .052 \\
\hline & Accommodation Facility Stars & 3.279 & 1.595 & 1.228 & 2.056 & .000 \\
\hline & Service Capacity & -.367 & .088 & -.514 & -4.136 & .024 \\
\hline & $\begin{array}{l}\text { Socio-demographic } \\
\text { Characteristics }\end{array}$ & .197 & .575 & .149 & 1.134 & .073 \\
\hline a. Dependent Variable: Guests' score on eco effect of accommodation facilities \\
\hline
\end{tabular}

Source: The author's calculations based on Survey data, 2015

Values of regression coefficient in the observed model for variable Accommodation Facility Stars is 1.208 with significance 0.000 . Based on that, with the error risk under $1 \%$, it may be concluded that, theoretically, in case other predictors remain unchanged, every increase in category for an additional star results in 1.208 higher guests' score for eco-effect of facility.

\section{Discussion: Assessment of the degree of environmental responsibility in hospitality management}

In this section the quality of the analysis presented in the section above is examined. Some of the risks are typical for this kind of research, but some risks are specific to this particular study.

In the Republic of Serbia, the legal framework for the development of environmental responsibility in tourism and hospitality industry includes documents from higher (the Constitution) to lower level(specific laws and regulations). Guests' view of the environmental responsibility in rural accommodation industry was provided by the research.

In addition to the fact that guests gave subjective answers to questions related to the need for introduction of (voluntary) environmental standards in the accommodation industry, some of the answers deserve attention to be paid to them. High average score for attitude - accommodation facilities that received the eco-label are better positioned in the market - shows that the guests in rural accommodation in Vojvodina are aware of the market benefits of "green" facilities. Excellent average score received the opinion - Serbia should introduce one of the internationally recognized eco-labels for the accommodation facilities - which indicate the confidence in the international eco-labels, although guests were not familiar with the standards prescribed by them. At the same time, the majority supported the position - Serbia should introduce its own eco-label for accommodation industry - which may be confusing, but according to additional explanations by the guests, although they trust international eco-labelling, they express doubt into implementation of certain standards without difficulties.

Therefore, as initial solution, there is prevailing opinion that fist national eco-labelling should be introduced through a separate label added to the star rating system in Serbia. 
Although it is evident that there is still unclear view of what should be fulfilled, and what would be the actual profit from the introduction of environmental labelling. Relatively high average scores for the claim - Accommodation facilities should aspire to join the system of eco-labelling if introduced in Serbia, is encouraging. It shows that guests understand the necessity to improve the environmental image of Serbian hospitality (Hypothesis 2 proven). The initiative for the adoption, implementation and control of environmental labels in Serbian tourism and hospitality industry, guests leave to the Government. In their comments, they are not completely certain about the specific steps government should take, but there is the general interest for such programs. The obtained results indicate that in Serbia, or Vojvodina (at the moment), there is no professional or consumer association which would have enough strength and influence to implement eco-labels.

Although it is general opinion that for application of ecological standards capital investments are needed, it should be noted that majority of them are organizational and may be easily and quickly applied. The fact certainly highlights the need for training managerial structures in facilities, as well as the urgent information for the guests to make them aware of ecologically responsible business advantage. Possible educational brochures would aim at directing the guests to perceive environmental problems and make joint efforts to help preserve the environment.

Significant (positive) impact of facility category to its ecological image imposes the conclusion that the most suitable form of introducing ecological standards in hospitality is the additional label to the existing grading (star rating) system - introduction of new special type of accommodation -eco-accommodation. Special type of accommodation facilities would have an additional label (added to the stars) that the facilities obtain according to the fulfilment of prescribed standards for certain special type which may lead to competitive advantage since they attract certain target groups of consumers. Eco-accommodation specialization is imposed as a possible legal framework (Hypothesis 3 proven).

\section{Conclusions}

This paper did not discuss particular standards the accommodation facilities willing to introduce ecological label must fulfil, but only the possibility of introducing the system of eco-labelling in hospitality in Serbia that would be recognizable for the guests. According to the survey, the most convenient and the most feasible form of promotion ecological responsibility in hotel industry is through the implementation of eco-labels.

Previous analysis of the study indicates that the introduction of eco-labels could be carried out through Eco-accommodation label.

From the point of view of environmental policy, the survey results indicate that some, but not all, situations are win-win. Considering the example of introducing of other standards, basic standards of environmental responsibility should be imposed on all hospitality facilities, leaving the higher level of standards with possible eco-labelling as a voluntary option. As the awareness on positive effect of implemented standards 
grows, the number of accommodation facilities with eco-labels will grow due to their competitive advantage at the market. Additional stimulus to the process of obtaining eco-label would be to reduce tax liabilities for these facilities, which is common practice in developed countries.

Our research did not address the eco-labels for rural tourism, but rural tourists perception of eco labels for accommodation facilities. Future research could include the survey of tourists in urban areas regarding eco-labelling and comparison of their responses with responses of tourists in rural areas.

\section{Literature}

1. APAT Tourists accommodation EU eco-label award scheme - Final report. Italian National Agency for the Protection of the Environment and for Technical Services, Rome, Italy, 2002.

2. Bhattacharya, C.B., Sankar, S., Korschun D. (2008): Using Corporate Social Responsibility to Win the War for Talent. MIT Sloan Management Review, Massachusetts Institute of Technology, Vol. 49 No. 2, pp. 37-44, Cambridge, USA.

3. Bradić, M. (2011): Hotel Industry in Context of responsible Tourism Development, Ph.D. dissertation, University of Novi Sad, Faculty of Science, Novi Sad, Serbia.

4. Gajić, A. (2015): Different methodological approaches in defining rural and urban areas. Architecture and urbanism, Institute of architecture and urbanism of Serbia, Vol. 41, pp. 63-67.

5. GHA - What are green hotels?, Green Hotel Association (GHA), 2014, URL http://www.greenhotels.com/whatare.htm (accessed on May 10th, 2012).

6. Gossling, S. (2002): Global environmental consequences of tourism. Global Environmental Change, Elsevier, Vol 12, No 4, pp. 283-302.

7. Han, H., Hsu, L.T.J., Sheu, C. (2010): Application of the Theory of Planned Behaviour to green hotel choice: Testing the effect of environmental friendly activities. Tourism Management, Elsevier Vol 31, No. 3, pp. 325-34.

8. Holcomb, J.L., Upchurch, R.S., Okumus, F. (2007): Corporate social responsibility: what are top hotel companies reporting?. International Journal of Contemporary Hospitality Management, Emerald, Vol. 19, No. 6, pp. 461475.

9. Hooi, A.W.K. (2009): Competitiveness Through Sustainability In The Tourism Industry, International conference on green industry, Manila, Philippines.

10. Guide to energy-efficient building, IHP - Institute Hrvoje Pozar, The Ministry of Environmental Protection, Spatial Planning and Construction of the Republic of Croatia - Office for housing, municipal management and buildings, the Department of Civil Engineering and Energy, Zagreb, 2005. 
11. ISO 14020, Environmental labels and declarations - General principles, ISO, 2015.

12. Juwaheer, T. D. (2004): Exploring international tourists' perceptions of hotel operations by using a modified SERVQUAL approach - a case study of Mauritius. Managing Service Quality: An International Journal, Emerald, Vol. 14, No. 5, pp. $350-364$.

13. Karagiorgas, M., Tsoutsos, T., Drosou, V., Pouffary, S., Pagano, T., Lara, G.L. (2006): HOTRES: renewable energies in the hotels. An extensive technical tool for the hotel industry. Renewable and Sustainable Energy Reviews, Elsevier, Vol. 10, No. 3, pp. 198-224.

14. Kasim, A., Garsoy, D., Okumus, F., Wong, A. (2014): The importance of water management in hotels: a framework for sustainability through innovation. Journal of Sustainable Tourism, Taylor \& Frances, Vol. 22, No. 7, pp. 10901107.

15. Keller, M. (2010): Managing grapevines to optimise fruit development in a challenging environment: a climate change primer for viticulturists, Australian Journal of Grape and Wine Research, Wiley, Vol. 16, No. 1, pp. 56-69.

16. Kelly, J., Haider, W., Williams, P.W., Englund, K. (2007): Stated preferences of tourists for eco-efficient destination planning options. Tourism Management, Elsevier, Vol 28, No. 2, pp. 377-390.

17. Laroche, M., Bergeron, J., Barbaro-Forleo, G. (2001): Targeting consumers who are willing to pay more for environmentally friendly products. Journal of Consumer Marketing, Emerald, Vol. 18, No. 6, pp. 503-520.

18. Manaktola, K., Jauhari, V. (2007): Exploring consumer attitude and behaviour towards green practices in the lodging industry in India. International Journal of Contemporary Hospitality Management, Emerald, Vol. 19, No. 5, pp. 364377.

19. The 3R Guidebook for Hotels, National Environment Agency (NEA) and Singapore Hotel Association (SHA), Singapore, 2006.

20. Cut Company Costs by Cutting Company Wastes, NCDPEA - The North Carolina Division of Pollution and Environmental Assistance, North Carolina, 2010 .

21. Nikolau, J. L. (2008): Corporate Social Responsibility - Worth-Creating Activities. Annals of Tourism Research, Elsevier, Vol. 35, No. 4, pp. 990-1006.

22. Passive House Solutions - Promotion of European Passive Houses, European Commission under the Intelligent Energy Europe Programme. EIE/04/030/ S07.39990, 2006.

23. Randelli, F., Romei, P., Tortora, M. (2014): An evolutionary approach to the study of rural tourism: The case of Tuscany. Land Use Policy, Elsevier, Vol. 38, pp. 276-281. 
24. Stojanović, V. (2006): Sustainable Development of Tourism and Environment, $1^{\text {st }}$ edn. Pp. 78-131. Department of Geography, Tourism and Hotel Management, Faculty of Science, Novi Sad.

25. Sweeting, J.E.N., Sweeting, A.R. (2003): A practical guide to good practice managing environmental and social issues in the accommodations sector, United Nations Environment Programme (UNEP).

26. Tomescu, A. M. (2011): Aspects of service Quality and Eco labelling of Romanian Lodging Services. Proceedings from the conference - European Integration - New Challenges, Oradea, Romania, pp. 693-699.

27. Tsagarakis, K., Bounialetou, F., Gillas, K., Profylienou, M., Pollaki, A., Zografakis, N. (2011): Tourists' attitudes for selecting accommodation with investments in renewable energy and energy saving systems. Renewable and Sustainable Energy Reviews, Elsevier, Vol. 15, No. 2, pp. 1335-1342.

28. Factors and Initiatives affecting Renewable Energy Technologies use in the Hotel Industry, Hotel Energy Solutions project publications, World Tourism Organization, UNWTO, 2011.

29. Waldmann, J. (2005): Protecting the Environment in the European Union, In: Meyers M, Woyke W, editors. Introduction to European Studies, Münster: Klausenburg. 


\title{
EKO-OZNAČAVANJE SMEŠTAJNIH OBJEKATA I PERCEPCIJA RURALNIH TURISTA: STUDIJA SLUČAJA VOJVODINA
}

\section{Milan Bradič ${ }^{6}$, Ljiljana Kosar ${ }^{7}$, Lukrecija Djeri, Svetlana Vukosav ${ }^{9}$, Vuk Garača $^{10}$}

\begin{abstract}
Rezime
Zajedno sa transportom, ekološka efikasnost hotelijerstva čini osnovu ekološke efikasnosti celokupnog turističkog poslovanja. Iako je turistička delatnost ogroman potrošač resursa, neveliki broj istraživanja se bavio odgovornošću u pogledu stavova različitih činilaca turističkog poslovanja. Jedan od krajnjih ciljeva održivog razvoja je podsticanje odgovornog ponašanja ne samo turoperatera, već i samih turista.

Ovaj rad predstavlja rezultate kvantitativnog i kvalitativnog istraživanja koje je sprovedeno u 59 smeštajnih objekata u ruralnim područjima Vojvodine.

Glavni cilj je bio istraživanje mogućnosti unapređenja ekoloških aspekata odgovornog ponašanja potrošača u hotelijerskoj delatnosti. Zadatak istraživanja je shvatanje prirode odnosa između pozitivnih ekoloških stavova turista i odgovornosti turističke privrede koja se ogleda u novim standardima u turističkoj delatnosti.
\end{abstract}

Ključne reči: održivi turizam, ruralni turizam, hotelijerstvo, eko-označavanje, ekološki menadžment

6 Docent, dr Milan Bradić, Univerzitet u Novom Sadu, Departman za geografiju, turizam i hotelijerstvo, Trg Dositeja Obradovica br. 3, Novi Sad, Srbija, Telefon: +381 21 4852 848, E-mail: milanbradic@gmail.com

7 Redovni profesor, dr Ljiljana Kosar, Visoka hotelijerska škola, Kneza Viseslava Ulica br. 70, Beograd, Srbija, Telefon: +381 112543 972, E-mail: ljiljakosar@hotmail.com

8 Vanredni profesor, dr Lukrecija Djeri, Univerzitet u Novom Sadu, Departman za geografiju, turizam i hotelijerstvo, Trg Dositeja Obradovica br. 3, Novi Sad, Srbija, Telefon: +381 21450 105, E-mail:djerilukrecija@gmail.com

9 Docent, dr Svetlana Vukosav, Univerzitet u Novom Sadu, Departman za geografiju, turizam i hotelijerstvo, Trg Dositeja Obradovica br. 3, Novi Sad, Srbija,, Telefon: +381 21 4502 848, E-mail: cecamobr@yahoo.com

10 Docent, dr Vuk Garača, Univerzitet u Novom Sadu, Departman za geografiju, turizam i hotelijerstvo, Trg Dositeja Obradovica br. 3, Novi Sad, Srbija, Telefon: +381 21 4502 836, E-mail: vuk garaca@yahoo.com

EP 2017 (64) 1 (205-219) 
ECONOMICS OF

AGRICULTURE

\section{CONTENT}

1. Željko Anđelković, Aleksandra Dragin, Sanja Božić, Kristina Košić

EMOTIONAL EXHAUSTION AND JOB SATISFACTION OF TOUR GUIDES IN RURAL AREAS . . . . . . . . . . . . . . 11

2. Sanja Đukić, Danica Glavaš-Trbić, Nikola Banjac

MANAGEMENT PROBLEMS OF RURAL DEVELOPMENT IN FRUŠKA GORA . . . . . . . . . . . . . . . . . . . . 27

3. Ivana Ilić, Bojan Krstić, Sonja Jovanović

ENVIRONMENTAL PERFORMANCES OF AGRICULTURE IN THE EUROPEAN UNION COUNTRIES . . . . . . . . . . . . . 41

4. Nataša Kljajić, Jonel Subić, Zorica Sredojević

PROFITABILITY OF RASPBERRY PRODUCTION

ON HOLDINGS IN THE TERRITORY OF ARILJE. . . . . . . . . . . 57

5. Aleksandar Maksimović, Zoran Grgić, Ferhat Ćejvanović

MULTI-ATTRIBUTE ANALYSIS OF ORCHARD ACCORDING

TO THE INTEGRATED PRODUCTION CONCEPT . . . . . . . . . . 69

6. Ozrislava Milinković, Branislav Jakić, Slobodan Vuksanović,

Dragana Macura, Milica Šelmić

MULTI- CRITERIA DECISION BASED APPROACH

TO SELECTING THE TYPE OF INDUSTRIAL HALLS

USED IN FOOD INDUSTRY $\ldots \ldots \ldots \ldots$. . . . . . . . . . 81

7. Gordana Nikić, Ljubiša Stamatović, Azra Sućeska

EMOTIONAL COMPETENCIES AND PERSONALITY

TRAITS OF MANAGERS IN MODERN AGROBUSINESS. . . . . . . .97

8. Vladimir Obradović, Nemanja Karapavlović

FINANCIAL REPORTING OF COMPREHENSIVE INCOME

IN THE FOOD AND BEVERAGE SECTOR

IN THE REPUBLIC OF SERBIA . . . . . . . . . . . . . . 113 
9. Aleksandar Ostojić, Nebojša Savić, Željko Vaško

CONSUMER ATTITUDES

ON BUYING FISH IN BANJA LUKA . . . . . . . . . . . . . . . 129

10. Radivoj Prodanović, Boris Kuzman, David Jovović, Lazar Ozegović

MARKET AND TRADE OF ORGANIC FRUITS IN SERBIA $\ldots . . .141$

11. Predrag Vukadinović, Aleksandar Damnjanović, Ljiljana Dimitrijević

ANALYSIS OF THE SALES AND INCOMES BETWEEN

DIFFERENT CATEGORIES OF AGRICULTURAL PRODUCTS . . . 157

12. Jugoslav Aničić, Svetlana Vukotić, Goran Maksimović

THE POSSIBILITIES AND LIMITATIONS

OF ENTREPRENEURSHIP DEVELOPMENT

IN AGRICULTURE IN SERBIA . . . . . . . . . . . . . . 171

13. Željko Bjelajac, Marijana Dukić - Mijatović, Joko Dragojlović

FOOD SAFETY AS ONE OF THE MAIN SAFETY $P$

REOCCUPATIONS OF A MODERN MAN . . . . . . . . . . . . . 191

14. Milan Bradić, Ljiljana Kosar, Lukrecija Djeri, Svetlana Vukosav, Vuk Garača

ECO-LABELLING OF ACCOMMODATION FACILITIES

AND ITS PERCEPTION BY RURAL TOURISTS:

CASE STUDY OF VOJVODINA . . . . . . . . . . . . . . 205

15. Vaso Jegdić, Iva Škrbić, Srđan Milošević

MODELS OF ENTREPRENURSHIP DEVELOPMENT

IN RURAL TOURISM DESTINATIONS IN VOJVODINA . . . . . . . 221

16. Duško Kuzović

MUSEUM OF VERNACULAR ARCHITECTURE OF WESTERN SERBIA

- Representative curtilages of the area surrounding middle

course of the river Drina and Podgorina . . . . . . . . . . . 239

17. Branko Mihailović, Zoran Simonović, Nikola Ćurčić

AGRICULTURAL RESOURCES AND DEVELOPMENT

PRIORITIES OF THE MUNICIPALITY OF STARA PAZOVA. . . . . 259

18. Radmilo Nikolić, Aleksandra Fedajev, Vidoje Stefanović, Silvana Ilić

THE AGRICULTURE SECTOR IN WESTERN BALKANS

- SOME CHARACTERISTICS OF DEVELOPMENT. . . . . . . . . . 275

19. Vladimir Njegomir, Rajko Tepavac, Nenad Ivanišević

ALTERNATIVE SOURCES OF FINANCING

ENTREPRENEURIAL UNDERTAKINGS IN AGRICULTURE . . . 295

Economics of Agriculture, Year 64, No. 1 (1-404) 2017, Belgrade 
20. Daniela Nuševa, Kristina Mijić, Dejan Jakšić

THE PERFORMANCES OF COFFEE PROCESSORS

AND COFFEE MARKET IN THE REPUBLIC OF SERBIA . . . . . . 307

21. Svetlana Roljević Nikolić, Predrag Vuković, Biljana Grujić

MEASURES TO SUPPORT THE DEVELOPMENT OF ORGANIC

FARMING IN THE EU AND SERBIA . . . . . . . . . . . . 323

22. ŽeljkoVojinović, Vera Zelenović, DragoCvijanović

PROGRAM OF STATE SUPPORT

TO AGRICULTURAL CREDITING. . . . . . . . . . . . . . . . 339

23. Nikola Vuksanović, Dragan Tešanović, Bojana Kalenjuk,

Milijanko Portić, Marija Knežević

SOCIO-DEMOGRAPHIC CHARACTERISTICS

AS DETERMINANTS OF DIFFERENCES

IN PERCEPTION OF LOCAL GASTRONOMY . . . . . . . . . . . . 359 